\title{
WHAT HAS INTERNATIONAL PRIVATE LAW ACHIEVED IN MEETING THE CHALLENGES POSED BY GLOBALISATION?
}

\author{
P. WAUTELET \\ ASSOCIATE PROFESSOR OF LAW, UNIVERSITY OF LIĖGE \\ ATTORNEY AT LAW, BRUSSELS
}

I. Introduction

II. National and international rules of jurisdiction

III. Common Principles of Private International Jurisdiction?

1. Territorialism as a sole justification / limitation for jurisdiction has been abandoned

2. Consent is generally recognised as a satisfactory base for jurisdiction

3. $\quad$ Prohibition of 'jurisdictionally improper fora'

IV. An attempt to conclude : the differences that separate us

\section{Introduction}

1. The issue of jurisdiction certainly constitutes one of the main challenges of what is commonly called 'globalisation', i.e. the rapid internationalisation of economic (and, to a somewhat lesser extent, of other) activities. Since legal regulation of these human activities is still largely state-based - with the notable exception of the European Union, whose existence and the large body of rules it produces, also raises questions of jurisdiction - rules on jurisdiction are necessary to define which part of these activities can be subject to regulation by a given State.

This paper aims to examine what private international law has achieved to answer the question of jurisdiction. ${ }^{1}$ Before doing so, one needs to define what must be understood by 'jurisdiction' in private international law.

2. Jurisdiction has been defined as "the State's right under international law to regulate conduct in matters not exclusively of domestic concern". ${ }^{2}$ As classic as Mann's statement, is the distinction between different categories of jurisdiction. The right of regulation of a State can be exercised in different ways. It has become commonplace to distinguish between the jurisdiction to prescribe (i.e. to make its law applicable to activities and relations, whether by legislation, regulation or determination of a court), jurisdiction to adjudicate (i.e. to subject persons or things to process of courts) and finally jurisdiction to enforce (i.e. to induce or compel compliance, through courts or by use of executive, administrative, etc.). ${ }^{3}$

3. What has private international law to say on these questions? The question of the relationship between private international law and jurisdiction is a vexed one, as is more generally the issue of the relationship between private international law and international

\footnotetext{
1 For recent accounts of the impact of globalisation on transnational litigation, see A. S. Bell, Forum Shopping and Venue in TRANSNATIONAL Litigation, Oxford Private International Law Series, Oxford, OUP, 2003, at pp. 1-5 and H. P. Glenn, Globalization and Dispute Resolution, 19 CIVIL JUSTICE QUARTERLY 136 (2000).

2 F. A. MANN, The Doctrine of Jurisdiction in International Law, ColleCted Courses OF THE HAGUe ACADEMY FOR INTERNATIONAL LAW 1964-I, at p. 2. Another definition is that of Reisman, who sees jurisdiction as the process of "allocating to particular states the competence to make or apply law to particular persons, things or events that are, simultaneously or sequentially, claimed by or subject to, the control of two or more states" (W. M. Reisman, JURISDICTION IN INTERNATIONAL LAW, Ashgate, Dartmouth, 1999, p. xi).

3 See $\S 401,3^{\text {rd }}$ Restatement Foreign Relations Law of the United States.
} 
law. ${ }^{4}$ It is tempting to think that the three classic categories of jurisdiction correspond to the three main questions addressed by private international law - that of the law applicable to a transnational relationship, that of the jurisdiction of national courts to rule on a dispute concerning such a relationship and finally the question of the enforcement of foreign judgments.

However, a close analysis reveals that the link between 'jurisdiction' as defined in international law and the three issues dealt with by private international lawyers is not obvious, nor always direct. No question exists that private international law rules determining the circumstances in which a national court can rule on a dispute involving elements from different States have a direct link with jurisdiction as understood here. The same goes for those rules dealing with the enforcement of foreign judgments. In these two cases, the rule aims to determine when a court of a given state can address an international situation, i.e. it determines the limits in which a state can exercise its jurisdiction through its courts - or, when a foreign judgment has been rendered, when this judgment can be considered to have been issued by a court which could legitimately exercise jurisdiction over the case. ${ }^{5}$ The link between jurisdiction and rules of private international jurisdiction is obvious, since the latter determine the sphere of influence of national courts.

4. Private international law also contains rules which aim to resolve the question of legislative diversity - which law is applicable to a situation with transnational aspects. These rules come in different shapes and models - from the traditional conflict of laws rule, based on the Savignian model, determining indirectly and abstractly which national law is applicable, to a more direct method, which imposes the international application of a given rule of national law. ${ }^{6}$

The link between jurisdiction and these rules (the conflict of laws rules in the strict sense) is less obvious. Can it be said that a rule according to which the marriage between persons of different nationalities is subject to the requirements (minimum age, relationship of kin etc..) laid down by the national laws of the future spouses, ${ }^{7}$ touches upon the jurisdiction of these States?

As is known, there has been an evolution in the way private international lawyers think about this question. During much of the $19^{\text {th }}$ century, rules of conflict of laws - at least those determining the national law applicable to a transnational situation - were said to delimit the competence of the States involved. By determining which law was applicable to a relationship, conflict of laws rules were said to describe the territorial sphere of application of national laws, and hence also the limits of each sovereignty. ${ }^{8}$ In this

4 See generally J. VERHOEVEN, Droit international public et droit international privé : où est les différence ?, ARCHIVES DE PHILOSOPHIE DU DROIT, 1987, 23-34.

5 This is however contested; for some, rules of recognition and enforcement have no bearing on the issue of jurisdiction as they do not directly invest a foreign court with jurisdiction, see $P$. Mayer, Droit international privé et droit international public sous l'angle de la notion de compétence, REVUE CRITIQUE DE DROIT INTERNATIONAL PRIVÉ, 1979, (1-29, 349-388 and 537-583), 18.

$6 \quad$ For an account of this diversity, see e.g. TH. DE BOER, "Een 'zoo doeltreffend en rechtvaardig mogelijke ordening'. Vragen rond de bestaansgrond van het internationaal privaatrecht", Royal Dutch Academy of Sciences, Communications of the Section on Literature, New Series 59/1, Amsterdam, Noord-Hollandsche, 1996, 58 p., in particular at pp. 19-37.

7 A rule traditionally found in the laws of Roman-Germanic countries, see e.g. L. PALSSON, "Marriage and Divorces », in International Encyclopedia of Comparative Law, Vol. III : Private International Law, Chap. 16, Tübingen, J.C.B. Mohr Siebeck, 1978, 171 p.

$8 \quad$ Hence conflict of laws were seen as 'conflits de souverainetés'; and the emphasis put e.g. on renvoi. See generally, P. MAYER, Le mouvement des idées dans le droit des conflits de lois, DROITS. REVUE FRANÇAISE DE THÉORIE JURIDIQUE, 1985, 129-143. 
approach, the distinction between international law and private international law was blurred, both were considered to be part and province of the 'law of nations'.

It is only gradually that private international lawyers came to accept that conflict of laws rules (in the strict sense) also serve private interests and, hence, that the rules determining which law is applicable to a given relationship do not necessarily impact on the sovereignty of the (foreign) State whose law is declared applicable. The function of the conflict of laws rule came to be seen as simply to resolve private international situations, without necessarily passing a judgment on the sovereignty or jurisdiction of foreign States. Under this model, the rule of State $X$ prescribing application of the law of State $Y$ or of State $Z$, does not in essence deal with jurisdiction of these States. State $X$ simply borrows the law of State $Y$ or $Z$ for application in a given situation, or State $X$ accepts that his own law will apply. At most, these rules tell us in which situations State $X$ accepts that its laws do or do not apply.

The view that conflict of laws rules do not have any bearing on jurisdiction, on the 'power to regulate' of the States concerned, is certainly not uncontested. ${ }^{10}$ It should also be qualified : only the most traditional approach focuses exclusively on private interests, and in particular on the so-called 'Sitz' of the relationship at hand, to determine which law applies. One cannot forget that there are other methods of resolving a situation of legislative diversity than the indirect and abstract conflict of laws rule devised by Savigny. It is enough to refer in this respect to the phenomenon of internationally mandatory rules, i.e. particular rules of national law that are deemed too important to tolerate application of foreign law. ${ }^{11}$ When State $X$ elevates one of its rules to the level of internationally mandatory, this State excludes the application of any foreign law. This decision has a more direct bearing on the issue of jurisdiction, as internationally mandatory rules will almost always go together with a rule reserving jurisdiction to the courts of the State concerned. In this sense, this method has a more direct link with the issue of jurisdiction. Furthermore, internationally mandatory rules are in effect direct translations of particular state policies, whose enforcement the State wants to guarantee even in international cases.

5. The debate between the 'private' and the 'public' function of the conflict of law rules will certainly go on. Given the uncertainty surrounding the relationship between jurisdiction and rules relating to the applicable law, the following will be exclusively focused on the rules of private international jurisdiction.

Rules of private international jurisdiction have been around for as long as lawyers have thought about cross-border relationships. Before examining whether it is possible to find any common ground ${ }^{12}$ in the way lawyers of different nations think about jurisdiction (III), it is important to examine who decides on jurisdiction (II).

The epitome of this view is to be found with Bartin's thinking, according to which private international law has as its object to "délimiter, en fixant les justes limites de chacune d'elles, les différentes souverainetés dans leur double fonction législative et juridictionnelle de droit privé" (PRINCIPES DE DROIT INTERNATIONAL PRIVÉ, vol. I, Paris, 1931, p. 55, § 122).

10 The idea that conflict of laws rules are not part of a 'Grenzrecht' has been challenged, most recently and most brilliantly by $P$. de Vareilles Sommières, LA COMPÉTENCE INTERNATIONALE DE L'ETAT EN MATIĖRE DE DROIT PRIVÉ. DROIT INTERNATIONAL PUBLIC ET DROIT INTERNATIONAL PRIVÉ, Paris, LGDJ, 1997.

11 Also called the 'règles d'application immediate', see art. 7 of the 1980 Rome Convention on the Law Applicable to Contractual Obligations.

A phrase recently used by Prof. R. BRAND in a similar context, see his contribution entitled Jurisdictional Common Ground: In Search of a Global Convention, in J. NAFZIGER and S. SYMEONIDES (eds.), LAW AND JUSTICE IN A MULTI-STATE WORLD: EsSAYS IN HONOR OF ARTHUR TAYLOR VON MEHREN, Ardsley, NY, Transnational Publishers, 2002, pp. 11-32. 


\section{National and international rules of jurisdiction}

6. Before attempting to discover if State practices reveal any common on the issue of jurisdiction, it should be made clear that jurisdiction is not primarily, or at least not exclusively, an international issue. Most issues of jurisdiction will be settled at the national level, using national rules. The courts of State A will for instance refer to the rules laid down by State $A$ to decide if they can take up a case brought by a citizen of State A against a citizen of State B. Whatever State B holds on jurisdiction generally speaking, and in the particular matter put to the courts of State $A$, is of no direct relevance to determine whether the courts of State A have jurisdiction. International law remains largely silent on the consequences of the wrongful exercise of jurisdiction (i.e. excess of jurisdiction). Put differently, there is no direct sanction for what State A decides in terms of jurisdiction. If State $B$ feels State $A$ has overreached its jurisdiction, it cannot directly prevent $A$ from taking jurisdiction. At most, B will interfere indirectly with A's claim for jurisdiction. State $B$ can for example refuse to enforce a judgment rendered by the courts of State A. State B can also accept jurisdiction itself as a way of reprisal. ${ }^{13}$ State B can finally enjoin the plaintiff in State $A$ to cease and desist. ${ }^{14}$ In some rare occurrences, jurisdictional overreach will lead to diplomatic protest. ${ }^{15}$

This is because international law of jurisdiction only limited ambitions. It is commonly accepted that customary international law does not contain detailed rules regulating the taking of jurisdiction in private matters by this or that national court. It merely provides for very general principles that limit the freedom of States in enacting their rules of jurisdiction.

At most, two basic principles can be deducted from customary international law, i.e. respect for immunities of foreign States ${ }^{16}$ and the prohibition of denial of justice. Outside these general principles, the discretion of States seems unfettered. As the Permanent Court of International Justice held in the famous Lotus-case,

"Loin de défendre d'une manière générale aux Etats d'étendre leurs lois et leur juridiction à des personnes, des bien et des actes hors du territoire, [le droit international] leur laisse, à cet égard, une large liberté, qui n'est limitée que dans

Several statutes provide that State B has jurisdiction only in so far as courts of State A would assume jurisdiction in a similar dispute, thereby extending national jurisdiction to reciprocate a claim by a foreign state, see for example article 636 of the Belgian Judicial Code, which, combined with Article 638 of the same Code, extends the reach of Belgian courts to disputes over which foreign courts also exercise jurisdiction. See for other examples, P. Lagarde, La réciprocité en droit international privé, COLLECTED COURSES, 1977-I, t. 154, (pp. 103-214), at pp. 149-150, n 47.

The so-called antisuit injunction, see Airbus Industrie GIE v. Jaisukh Arjun Bhai Patel and others [1999] A.C. 119, [1998] 2 All.E.R. 257, [1998] 2 W.L.R. 686, [1998] 1 Lloyd's Rep 631, (1998) 37 I.L.M. 1076 (H.L.). For classic studies of the subject, see T. C. HARTLEY, Comity and the Use of Antisuit Injunctions in International Litigation, AM. J. CoMP. L., 1987, 487-511; G. BERMANN, The Use of Anti-Suit Injunction in International Litigation, CoL. J. TRANS. L., 1990, 589-631; W. HAU, 191-192 and P. B. CARTER, Anti-suit Injunctions in Private International Law, Vorträge, Reden und Berichte aus dem Europa Institut $n^{\circ} 368$, Europa-Institut Universität des Saarlandes, 1997, 22 p. The subject of antisuit injunctions fascinates scholars well beyond common law, and has spawned a large literature over the last years, see S. CLAVEL, Le pouvoir d'injonction extraterritorial pour le règlement des litiges privés internationaux, PhD., Paris I, 1999; M. REQUEJO ISIDRO, Proceso en el extranjero y medidas antiproceso (anti-suit injunctions), De conflictu legum - estudios de Derecho internacional privado $n^{\circ}$ 1, 2000, 282 p.; M. MAACK, Englische antisuit injunctions im europäischen Zivilrechtsverkehr, Berlin, Duncker \& Humblot, 1999, $229 \mathrm{p}$.

On this issue, P. DE VAREILLES-SOMmièRES, supra, note 10, at pp. 239-240, §§ 387-388.

16 If the principle of immunity for foreign States is generally accepted, the limitations imposed on the immunity privilege vary greatly. For a recent study of the 'common ground' between States, see I. Pingel-Lenuzza, LES IMMUNITÉS DES ETATS EN DROIT ITNETRNATIONAL PUBLIC, Brussels, Bruylant, 1997. 
quelques cas par des règles prohibitives; pour les autres cas, chaque Etat reste libre d'adopter les principes qu'il juge les meilleurs ou les plus convenables". ${ }^{17}$

Even though the precise contours of the international law on jurisdiction are subject to debate, one can agree with M. Akehurst's conclusion to the effect that :

"In practice, the assumption of jurisdiction by a State does not seem to be subject to any requirement that the defendant or the facts of the case need have any connection with that State; and this practice seems to have met with the acquiescence by other States [...] It is hard to resist the conclusion that [...] customary international law imposes no limits on jurisdiction of municipal courts in civil trials". ${ }^{18}$

The only limit to the assertion of judicial jurisdiction by a State in private matters seems to be the competing assertions of other States. Fundamental rights, and in particular the right to fair trial, have also recently been invoked to limit the jurisdictional claims of States. Their role is however timid at best and will certainly not confine these claims to well defined limits. ${ }^{19}$

7. Two important lessons can already be learned from the absence of clear constraints on the taking of jurisdiction by national courts. In the first place, the lack of a well defined international framework for jurisdictional claims inevitably brings about the existence of competing claims for jurisdiction. Concurrent jurisdiction will be the norm, rather than the exception. As a rule, jurisdiction is by no means 'exclusive'. When State A claims jurisdiction for a given situation, this does not exclude the jurisdiction of other States, which are free to claim jurisdiction on their own. Jurisdiction is therefore said to be concurrent, rather than exclusive. Rules of customary international law granting exclusive jurisdiction to one State are indeed not frequent. ${ }^{20}$

In practice, the only way to achieve exclusive jurisdiction is to allocate jurisdiction by agreement between the States concerned. Hence the second lesson, i.e; that the lack of clear constraints imposed by international law creates an impetus and incentive for States to agree on shared rules for jurisdiction. If jurisdiction is primarily a national issue, this does not mean that States cannot agree to define limits within which their courts are allowed to exercise their jurisdiction.

Customary international law has not brought much for the resolution of private disputes. Treaties and conventions on the other hand have existed for long. The first treaties date back to the $18^{\text {th }}$ century. ${ }^{21}$ Since these first attempts, the number of treaties and

17 PCIJ, case 'Lotus', decision of 7 September 1927, Recueil des arrêts, $n^{\circ}$ 9, Publications de la CPJI, Leyden, Sijthoff, pp. 18-19.

18

M. AKEHURST, Jurisdiction in International Law, BRITISH YEARB. INT'L L., 1972-73, (145), 177.

See the attempt by P. Schlosser, Human Rights and Litigation, RIVISTA DIRITTO INTERNAZIONALE, 1990, $5 \mathrm{ff}$. to define the limits. The same may not be true in the United States, where the due process clause of the Constitution has, since the International Shoe ruling of the Supreme Court, dominated all thinking about jurisdiction - both domestic and international. See generally, A. Mirandes, LA COMPETENCE INTER-ÉTATIQUE ET INTERNATIONALE DES TRIBUNAUX EN DROIT DES ETATS-UNIS, Paris, Economica, 2002.

As Mann wrote, "It is no doubt evidence of the rudimentary state of international law and a matter for regret that international jurisdiction is almost always concurrent" ( $F$. A. MANN, supra, note 2 , at p. 4);

See the first treaties cited by M. FoELIX in his Traité de droit international privé ou du conflit des lois en matière de droit privé, 4th ed., Paris, 1866, vol. 1, 323, $\mathrm{n}^{\circ} 154$ and in particular Article 7 of the Treaty concluded between France and Russia on 11 January 1757 . See also the treaty between France and Swiss, concluded on 18 July 1823 and between the German States of Bavaria and Wurtemberg on 7 May 1821, on which K. LIPSTEIN, Unification of Jurisdiction : An Early German Example, in L'UNIFICAZIONE DEL DIRITTO INTERNAZIONALE PRIVATO E PROCESSUALE. STUDI IN MEMORIA DI MARIO GIULIANO, Padoue, Cedam, 1989, 543-558. 
conventions allocating jurisdiction between states has grown exponentially, in all fields of law where human activities is prone to cross national borders. Regional agreements - in Europe ${ }^{22}$ or in South America ${ }^{23}$ - have been a resounding success. This has undoubtedly incited more ambitious projects such as the one launched by the United States in the 1990's to negotiate a worldwide jurisdiction convention - although it has proven much more difficult to obtain agreement among the different parts of the world, witness the impasse reached by the Hague Judgments Project. ${ }^{24}$

When it comes to private international jurisdiction, national law still dominates in most parts of the world. It is only in Europe where, thanks to the integrating forces of the common market, national rules have given way to uniform, European rules. If agreement is to be found on a truly international plane, one needs therefore to identify first what separates and what unites the different national traditions. With this general background in mind, we can now turn to the question of what has been achieved by private international law in terms of jurisdiction.

\section{Common Principles of Private International Jurisdiction ?}

8. The following account has only limited ambitions. It is concerned only with rules of private international jurisdiction, defined as rules dealing with adjudicative jurisdiction in what are essentially private matters. ${ }^{25}$

Tradition distinguished between rules of direct jurisdiction, which determine when a court can take jurisdiction and rules of indirect jurisdiction, which determine under which circumstances a foreign court could legitimately exercise jurisdiction -'recognition and enforcement'. In both questions, the issue of jurisdiction is the same : can the court of State $\mathrm{X}$ rightly exercise jurisdiction over this piece of litigation? In the second branch of civil jurisdiction, the question is however asked with regard to a foreign court.

9. The latter branch of the alternative could provide useful insights on what is acceptable and what is not when it comes to jurisdiction. The enforcement practice of States indeed constitutes the 'acid test' of jurisdiction : if State B accepts to enforce a judgment rendered by State $A$, then it can be presumed that it finds nothing objectionable in the jurisdiction claim made by State $A$. The court addressed will indeed almost systematically enquire into the jurisdiction of the court of origin. An enquiry into the enforcement practice of States would therefore produce a detailed picture of the boundaries of jurisdiction.

22 G. A. L. Droz, L'harmonisation des règles de conflit de lois et de juridiction dans les groupes régionaux d'Etats, in RAPPORTS GÉNÉRAUX AU VIĖME CONGRĖS INTERNATIONAL DE DROIT COMPARÉ, Brussels, Bruylant, 1964, (393), 411-433.

In Latin America, see the Treaty of Montevideo of 1899, revised in 1940, in force in Argentina, Urugay, Paraguay, Bolivia and Peru. See also the Bustamente Code of 1928 and generally J. Samtleben, Internationales Privatrecht in Lateinamerika. Die Codigo Bustamente in Teorie und Praxis, Tübingen, Mohr, 1979, 58 e.s. as well as M. A. VIEIRA, "Le droit international privé dans le développement de l'intégration latino-américaines", Recueil des cours, 1970, II, 351-453, spéc. pp. 398-402. More recently, the Buenos Aires Protocol of 1994 (published in I.L.M., 1997, 1263) has followed the earlier examples, J. SAMTLEBEN, "Das internationale Prozeß- und Privatrecht des Mercosur. Ein Überblick”, RabelsZ., 1999, (1-69), spec. 32-45.

See the following two progress reports: A. T. VON MEHREN, "La rédaction d'une convention universellement acceptable sur la compétence judiciaire internationale et les effets des jugements étrangers : le projet de la Conférence de La Haye peut-il aboutir?", R.C.D.I.P., 2001, 85-99 and R. WAGNER, "Die Bemühungen der Haager Konferenz für Internationales Privatrecht um ein Übereinkommen über die gerichtliche Zuständigkeit und ausländische Entscheidungen in Zivilund Handelssachen. Ein Sachstandsbericht nach dem 1. Teil der Diplomatischen Konferenz", IPRax, 2001, 533-547.

25 These are defined as "civil and commercial issues" in European parlance. 
Such an enquiry goes beyond the limited scope of this paper. Furthermore, the enforcement practice of States depends in the first place on how the court addressed deals with indirect jurisdiction. The test can vary significantly. Under Belgian law for example, the jurisdiction of the court of origin is not part of the enquiry, except in the sole hypothesis where the court of origin asserted jurisdiction based on the nationality of the plaintiff, a clear condemnation of the infamous Article 14 of the French Civil Code. ${ }^{26}$ An enquiry of the Belgian practice would therefore not be very helpful, for it would only reveal that the nationality of the plaintiff is considered not sufficient to justify jurisdiction - a result that is too obvious. ${ }^{27}$ Under German law, a foreign judgment will receive recognition only if the foreign jurisdiction rule matches standards of German law (the socalled Spiegelbildprinzip). ${ }^{28}$ This mirror-image principle does not teach much more than the study of rules of direct jurisdiction. Conversely, French law has developed a rather flexible test, based on the requirement of a nexus between the claim and the court of origin. ${ }^{29}$ Unfortunately, the application of this sound principle does not lead to a system of clear and broad rules or statements as every case needs to be studied in its precise factual context. ${ }^{30}$

At most therefore, the enforcement enquiry could serve to validate negative conclusion, i.e. that some claims for jurisdiction are neither accepted nor acceptable. We will turn instead to a study of the practice of jurisdiction

10. Can general principles of private international jurisdiction be found? At most, one can distinguish three (modest) principles, which are likely to receive general assent. We will start with these generally accepted principles and move gradually to the more debatable issues.

\section{Territorialism as a sole justification / limitation for jurisdiction has been abandoned}

11. For a long time, it was thought that territorialism was the key, the sole justification for assertions of jurisdiction by courts. This idea was central to Story's thinking. ${ }^{31}$ In his classic Commentaries on the Conflict of Laws, the Supreme Court Justice offered the following statement of the territoriality doctrine as applied to judicial jurisdiction :

"Considered in an international point of view, jurisdiction, to be rightfully exercised, must be founded either upon the person being within the territory, or upon the thing being within the territory; for, otherwise, there can be no sovereignty exerted, upon the known maxim Extra territorium jus dicenti impune

26 See Article 570 of the Belgian Civil Code and our comments in "Artikel 570 Gerechtelijk Wetboek", dans : Gerechtelijk recht: artikelsgewijze commentaar met overzicht van rechtspraak en rechtsleer, J. LAENENS et al. (eds.), Antwerp, Kluwer, 1997, 38 p.

27 See infra on the prohibited grounds of jurisdiction.

28 See for comments on this method, F. K. JUENGER, "The Recognition of Money Judgments in Civil and Commercial Matters », Am. J. Comp. L., 1988, (1), 15.

29 This approach was pioneered in the Simitch-ruling of the French Court of Cassation 6 April 1985, published in the Revue critique de droit international privé, 1985, at p. 369 and in the Journal de droit international, 1985, at p. 460.

30 The courts in Canada have adopted a similar approach : Morguard Investments Ltd. v. De Savoye (1991) 76 D.L.R. (4th) 256; 282 (according to the Supreme Court, a foreign judgment should be recognised as along as the court of origin "properly, or appropriately, exercised jurisdiction in the action". This is the case when the court of origin "has a real and substantial connection with the action". Se also Hunt v. T. \& N. plc (1993) 109 D.L.R. (4th) 16 and United States of America v. Ivey, (1995) 130 D.L.R. (4th) 674.

31 On Story's contribution to private international law, see K. H. NADELMANN, "Observations sur la seconde édition des 'Commentaries ...' de Joseph Story à l'occasion de son bicentennaire", R.C.D.I.P., 1981, 1-15. 
non paretur... no sovereignty can extend its process beyond its own territorial limits, to subject either persons or property to its judicial decisions". ${ }^{32}$

American courts adhered strictly to these views during much of the $19^{\text {th }}$ century. This culminated with the twin statements issued by the Supreme Court in the Pennoyercase. ${ }^{33}$ According to the Court, "every state possesses exclusive jurisdiction and sovereignty over persons and property within its territory" and "no State can exercise direct jurisdiction and authority over persons and property without its territory". ${ }^{34}$

The corollary of this assertion was that "The foundation of jurisdiction is physical power". ${ }^{35}$

12. Most systems have outgrown this narrow, rigid territorialism. ${ }^{36}$ No reasonable lawyer will claim today that the courts of State $X$ can only rule upon disputes wholly localised within the borders of State $X$. This evolution was inevitable, economic changes dictated a more flexible approach to jurisdiction. Territorialism was found to be at once too narrow - for activities conducted outside the State, but with effect inside the State, escaped completely the jurisdiction of that State - and too broad since jurisdiction could also be founded on the temporary presence of the defendant. ${ }^{37}$

In the case law of the United States, the move away from the Pennoyer formula evolution was crystallized in the International Shoe formula, which still dominates jurisdictional thinking today. As the Supreme Court stated, "due process requires only that in order to subject a defendant to a judgment in personam, if he be not present within the territory of the forum, he have certain minimum contacts with it such that the maintenance of the suit does not offend 'traditional notions of fair play and substantial justice"'. ${ }^{38}$ The message was clear : a court can exercise jurisdiction even if the defendant is not immediately present in the territory under direct supervision by the court. The Court left the definition of these 'minimum contacts' to future rulings, which would be numerous but in many respects insatisfactory. ${ }^{39}$

32 J. STORY, Commentaries on the conflict of laws foreign and domestic in regard to contracts, rights and remedies, and especially in regard to marriages, divorces, wills, successions and judgments, $2^{\text {nd }}$ ed., Boston, Little \& Brown, 1841, § 539.

33

34 Pennoyer v. Neff, 95 U.S. 714, 24 L.Ed. 565 (1878).

95 U.S. 722.

As Justice Holmes held in McDonald v. Mabee, 23 U.S. 90, 91 (1917).

Territorialism is part of what Arthur von Mehren calls the 'power theory' in his "Adjudicatory Jurisdiction: General Theories Compared and Evaluated", Boston Univ. L. Rev., 1983, 279 ff.

On the many devices to escape the rigid limits on personal jurisdiction, see A. A. EHRENZWEIG, "The Transient Rule of Jurisdiction : the 'Power' Myth and Forum Conveniens", Yale L.J., 1956, 289-314.

International Shoe v. State of Washington, 326 U.S. 310, 316 (1945), per Chief Justice Stone (italics added).

Scholars have not been mild in their criticidm of the Supreme Court rulings, see P. J. BORCHERS, "Comparing Personal Jurisdiction in the U.S. and the European Community: Lessons for American Reform", Am. J. Comp. L., 1992, (121), 126-127 (according to Borchers, "In a area in wich stability and certainty are at premium, the Court's intervention has produced a haphazard jurisdictional doctrine that has left matters in an unacceptable posture. The Supreme Court has evinced great uncertainty as to, and a great preoccupation with, the theoretical underpinnings of its doctrine, while steering an erratic course that confuses courts, counsels, academicians and often the Justices as well"). In "A Map out of the Personal Jurisdiction Labyrinth", U. C. Davis L. Rev., 1995, 531-559, at p. 531, R. J. Weintraub explained that the case law of the Supreme Court "has added layer upon layer of complexity to the due process test for personal jurisdiction and [...] as a result, the threshold determination of in personam jurisdiction has become one of the most litigated issues in state and federal courts [...]"). It is enough to read the title of numerous contributions published by F. K. Juenger to understand that the late author was not very found International Shoe and its legacy... :"American Jurisdiction: A Story of Comparative Neglect', U. Colo. L. Rev., 1993, 1 ff. ; "A Shoe Unfit for Globetrotting", U. C. Davis L. Rev., 1995, 1027 ff. And "Supreme Court 
Today, the idea that jurisdiction is not strictly bound by the national borders, seems trite, if not banal. It is enough to refer to the famous 'long arm statutes' that determine at the state level, the limits of jurisdiction of courts. ${ }^{40}$ The word 'long arm' already conveys the idea that the state borders are no longer irremediably closed. The $3^{\text {rd }}$ Restatement Foreign Relations Law of the United States states that

"In general, a State's exercise of jurisdiction to adjudicate with respect to a person or a thing is reasonable if, at the time jurisdiction is asserted : [...] (j) the person, whether natural or juridical, had carried on outside the state an activity having a substantial, direct and foreseeable effect within the state, but only in respect of such activity [...]" (§ $421(2))$.

European courts can similarly exercise jurisdiction in disputes involving persons or property located outside their national borders. Under Article 5-3 of the 44/2001 Regulation, ${ }^{41}$ a defendant domiciled in a EU State can be sued before the courts of another state "in matters relating to tort, delict or quasi-delict, in the courts for the place where the harmful event occurred or may occur". According to the Court of Justice, a court of a Member State can, in case of transborder pollution, exercise jurisdiction over the defendant even if the pollution originated in another Member State, provided the direct damage caused is felt in the Member State where the court sits - the effects doctrine applied to private jurisdiction. ${ }^{42}$

13. In reality it is the very concept of territoriality that has been abandoned, or at least questioned. ${ }^{43}$ How else to explain that courts are today no longer hesitant to issue extraterritorial rulings, that directly seek to impose certain effects outside the national borders? It is enough to invoke the long series of Dutch cases pertaining to cross border injunctions in intellectual property litigation to illustrate this new trend. ${ }^{44}$ Today, courts of all countries commonly enjoin defendants from committing acts abroad. ${ }^{45}$

Intervention in Jurisdiction and Choice of Law : A Dismal Prospect", U. C. Davis L. Rev., 1981, $907 \mathrm{ff} .$. Mann was also very critical. In his second Hague Academy lectures, he wrote that the Supreme Court "has led the lower courts to results which in many cases are unattractive and $[\ldots]$ unsatisfactory [...]. The general impression which [these cases] create [...] is that due process as understood in modern American law cannot provide firm guidance to the doctrine of international civil jurisdiction" (F. A. MANN, o.c., Recueil des cours, 1984-III, t. 186, 68).

See for an overview, G. B. BORN, International Civil Litigation in United States Courts. Commentary and Materials, $3^{\text {rd }}$ ed., Kluwer Law International, Boston, 1996, pp. 68-70.

Regulation 44/2001 adopted on 22 December 2000 (published in the O.J.E.C. of 16 January 2001, L-12/1 of 22) replaces the Brussels Convention of 27 September 1968 and lays down detailed rules on the jurisdiction of courts of EU Member States in civil and commercial matters; It also provides for the European equivalent of the US Full Faith and Credit Clause.

E.C.J., 30 November 1976, Bier v. Mines de Potasse d'Alsace, case 21/76, E.C.R., 1976, 1735.

43 M. RIGAUX, reporter of the Ninteenth Commission of the Institut de droit international, dealing with the issue of extra-territoral jurisdiction, refers in this respect to the "perte de confiance dans le caractère opérationnel des concepts mêmes de territorialité et d'extra-territorialité" : "Rapport provisoire sur la compétence extraterritoriale des Etats », Ann. Institut Droit International, vol. 68, 1998, (507), 509.

See generally M. Pertegás Sender, Cross-Border Enforcement of Patent Rights : An Analysis of the Interface between Intellectual Property and Private International Law, Oxford, Oxford University Press, 2002. See also H. BERTRAMS, "Das grenzüberschreitende Verletzungsverbot im niederländischen Patentrecht", GRUR Int., 1995, 193-201; J. J. BRINKHOF, "Het grensoverschrijdende verbod in octrooizaken in kort geding", Molengrafica. Europees privaatrecht 1995, Lelystad, 1995, 225-261; W. V. MEIBOM and J. PITZ, "Cross-Border Injunctions in International Patent Infringement Proceedings", E.I.P.R., 1997, 469-478; D. STAUDER, "Grenzüberschreitende Verletzungsverbote im gewerblichen Rechtsschutz und das EuGVÜ", IPRax, 1998, 317-322.

45 As has been observed, "il serait [...] particulièrement difficile d'invoquer l'existence d'une règle de droit international coutumier interdisant au juge d'ordonner l'accomplissement d'un acte à 
The demise of territoriality has been accompanied with proposals to replace this concept with new paradigms, such as the use of a 'reasonable link' - test to assess the exercise of jurisdiction. ${ }^{46}$ This raises other questions, which will be dealt with by Dr. Ralf Michaels in his study, Jurisdiction after Territory.

14. This does not mean that the idea of territory has lost all its relevance in delimitating jurisdiction. Many rules of jurisdiction recognise the importance of a direct link between the dispute and the territory under the jurisdiction of the court - witness the continued relevance of the actor sequitur principle. ${ }^{47}$ In disputes involving in rem property, the idea that the court where the property is located should have jurisdiction, is very much alive. ${ }^{48}$

The paradigm of territory is however no longer the only one accepted.

With the disappearance of a strict notion of territoriality as all-encompassing principle, the enforcement of judgments has gained increased importance. Since jurisdiction is no longer strictly tied to physical power over the defendant, there will be instances where a judgment cannot be enforced in the State where it was rendered. Hence the development of an important body of case law on enforcement, and the growing importance of international agreements dealing with the issue of enforcement, as reciprocity and mutual trust seems to be the motor of this question. ${ }^{49}$

\section{Consent is generally recognised as a satisfactory base for jurisdiction}

15. While territoriality is no longer the sole defining principle of jurisdictional claim, another general principle has gradually been accepted, which justifies the exercise of jurisdiction by reference to the consent of parties. Legal systems have indeed unmistakeably grown to recognise that parties to a contract or, more generally, to a legal relationship, can determine which court will hear their dispute.

This freedom has not been recognised overnight. There was a time when courts regarded choice of court clauses with distrust. In 1959, the Court of Appeal of the 5th Circuit could still refer to " [...] the universally accepted rule that agreements in advance

l'étranger; la pratique est trop répandue" : $\mathrm{P}$. KINSCH, Le fait du prince étranger, Paris, LGDJ, 1994, 134. See also P. SCHLOSSER, Der Justizkonflikt zwischen den USA und Europa, Berlin, Walter de Gruyter, 1985, 17 (the famous German jurist wrote that "Höchst selten hat man hierzulande Skrupel, zu einer Handlung verurteilen zu lassen, die im Ausland vorzunehmen ist" and at p. 21 "kann es keine Regel des Völkergewohneitsrechts geben, die es gerichten und Behörden eines Staates verböte, auf fremdem Territorium oder aus fremdem Territorium heraus vorzunehmende Handlungen auzuordnen und die Nichtbeachtung solcher Anordnungen zu sanktioneren").

See C. KeSSEDJIAN, International Jurisdiction and Foreign Judgments in Civil and Commercial Matters, Hague Conference on Private International Law, Preliminary Document $\mathrm{n}^{\circ} 7$, April 1997, 35-37. See also the review by H. Muir Watt of A. BUCHER's Droit international privé suisse. Tome 1/1 : Partie générale - Conflits de juridictions, Basel, Helbing et Lichtenhahn, 1998, published in Rev. Int'l. Dr. Comp., 1999, (1157), at pp. 1158-1159.

Generally, B. BUCHNER, Kläger- und Beklagtenschutz im Recht der internationalen Zuständigkeit, Tübingen, Mohr Siebeck, 1998, $170 \mathrm{p}$.

See Article 22 of the 44/2001 Regulation.

This also goes to show that when dealing with private international jurisdiction, one ought to take into account the parallel issues of enforcement and applicable law. One cannot design rules of jurisdiction without knowing what attitude the courts will take concerning foreign judgments. Inexplicably the Dutch rules of international jurisdiction were recently reformed, and adapted to modern thinking, while at the same time the antiquated Article 431 of the Dutch Code of Civil Procedure, prohibiting almost all extra-territorial effect of foreign judgments, remained in place. 
of controversy whose subject is to oust the jurisdiction of the Courts are contrary to public policy and will not be enforced ${ }^{50}$ The same could be said of arbitration, which was not always favorably viewed by courts jalous of their prerogatives.

This attitude of distrust has gradually disappeared to give way to a warm embrace. The "dramatic shift that American jurisprudence has taken from almost universal hostility towards exclusive forum clauses to enthusiastic acceptance" ${ }^{51}$ can be explained by the need to give businessmen certainty that what they bargained for will be upheld in court. As the Supreme Court held in the famous Zapata case "[t]he expansion of American business and industry will hardly be encouraged if, notwithstanding solemn contracts, we insist on a parochial concept that all disputes must be resolved under our law and in our courts". 52

16. The vast majority of legal systems recognise today the freedom for parties to a contract to decide which court will hear their dispute. It is enough to refer to the evolution of South American legal systems in this respect to show that the distrust has given way to a more than conciliant attitude, where parties enjoy a great freedom to shape their contracts also for issues of dispute resolution. ${ }^{53}$ It is true that certain legal systems have long resisted the recognition of this freedom. Companies doing business the Netherlands had to wait until 1985 to see the Ductch Supreme Court upholding a bargained for choice of court. ${ }^{54}$

However, much of the western world today could easily subscribe to the rule enshrined in Article 23 of the 44/2001 Regulation, which provides that "If the parties, one or more of whom is domiciled in a Member State, have agreed that a court or the courts of a Member State are to have jurisdiction to settle any disputes which have arisen or which may arise in connection with a particular legal relationship, that court or those courts shall have jurisdiction".

Recently, States negotiating at the Hague Conference for Private International Law have singled out choice of forum clauses as the main issue where they could probably find agreement ${ }^{55}$ - this in sharp contrast to the ambitious plans with which the negotiations for a worldwide Judgments Convention started in $1996 .{ }^{56}$

$50 \quad$ Carbon Black Export, Inc. v. S. S. Monrosa, 245 F.2d 297 (5th Cir. 1958), cert. denied 359 U.S. 1980 (1959).

51 E. F. Scoles, P. Hay, P. J. Borchers et S. C. Symeonides, Conflict of laws, $3^{\text {rd }}$ ed., St. Paul, West Publishing Co., 2000, 473.

52 M/S Bremen v. Zapata Off-Shore Co., 407 U.S. 1, 8 (1972). Some difficulties remain with choice of court clauses found in adhesion contracts, see W. M. RICHMAN, "Carnival Cruise Lines : Forum Selection Clauses in Adhesion Contracts", Am. J. Comp. L., 1992, 977-984 and L. MullenIX, "Another Easy Case, Some More Bad Law : Carnival Cruise Lines and Contractual Personal Jurisdiction", Texas Int'l L. J., 1992, 323-370.

In the past, courts in South America have long been reluctant to give effect to a contractual choice of court or an arbitration agreement. See for arbitration the situation in 1984, as described by A. M. GARRO, "Enforcement of Arbitration Agreements and Jurisdiction of Arbitral Tribunals in Latin America", J. Int'l. Arbitration, 1984, 293-321. Today, arbitration is widely recognised as a valid alternative to state court resolution: H. A. GRIGERA-NAÓN, "Overcoming Traditional Hostility Towards Arbitration" in International Commercial Arbitration. Recent Developments, Commercial Law \& Practice Course Handbook Series No. 477, II, New York, 1988, pp. 377-447 and B. M. CREMADES (ed.), Enforcement of Arbitration Agreements in Latin America, La Haye, Kluwer Law International/IBA, 1999, 250 p.

The famous Piscator case decide by the Hoge Raad on 1 Feb. 1985 (N.J., 1985, 698). See also for France, the ruling of the Court of Cassation of 1 December 1985, where the Court held that "[...] les clauses prorogeant la compétence internationales sont en principe licites, lorsqu'il s'agit d'un litige international [...]" (published in the Revue Critique de Droit international privé, 1985, at pp. 537, with comments by H. GAUDEMET-TALLON).

55 R. BRAND, "Forum Selection and Forum Rejection in U.S. Courts : One Rationale for a Global Choice of Court Convention“, in J. FAWCETT, Reform and Development of Private International 
17. The rise of arbitration as the preferred - if certainly not flawless $-{ }^{57}$ method for resolution of international business disputes also bears testimony to the ever increasing recognition of parties' consent as a general principle of jurisdiction. Most legal systems have sanctioned the possibility for parties to opt out radically of the judicial system and to entrust the resolution of their disputes to a private arbitral tribunal. By entrusting their disputes to a private tribunal, businesses hope to benefit from certainty, privacy, speed, commercial expertise and above all from neutrality. ${ }^{58}$

Even though significant differences remain, international commercial arbitration is today not only universally recognized as a valuable alternative to state justice, it can count on the active support of States who have concluded far reaching international agreements to ensure the respect for the findings of the arbitrators. ${ }^{59}$ What is more, States seem to be engaged in a sort of competition to devise liberal legislations supporting the arbitration process, with a view to attract what is perceived to be a lucrative or at least a prestigious business. ${ }^{60}$ Courts have also shown increased willingness to shake off the old judicial hostility to arbitration and in some cases are ready to cede jurisdiction to arbitral tribunals even when the controversy at hand involved special public policy considerations. ${ }^{61}$

In the same line, parties choose more and more today to forgo completely the idea of adjudication of their disputes by a neutral third party and opt for one or the other mechanisms embodying the idea of informal justice. Whatever the name, mediation,

Law - Essays in Honour of Sir Peter North, Oxford University Press, Oxford, 2002, at pp. 5187.

See on the whole project, ; A. F. Lowenfeld and L. J. Silberman (eds.), THE HAGUE CONVENTION on JURISDICTION AND JUDGMENTS. RECORDS OF A CONFERENCE HELD A NEW YORK UNIVERSITY SCHOOL OF LAW APRIL 30-MAY 1, 1999, New York, Jurispublishing, 2001 mult. pag. and S. Baumgartner, The Proposed HAgue Convention on JuRISDICTION AND Foreign Judgments. Trans-ATLANTIC LaWMAKING for TRANSNATIONAL LITIGATION, Mohr Siebeck, 2003, 210 p.

The advantages and drawbacks of party autonomy in the resolution of private international disputes have already been well documented, see e.g. W. W. Park, When and Why Arbitration Matters, in The Commercial Way to Justice. The 1996 InTERnAtional Conference of the ChARTERED INSTITUTE OF ARBITRATORS, G.M. Beresford Hartwell (ed.), Kluwer Law International, 1997, at pp. 73-99.

MAYER argues convincinly that neutrality is the main reason businesse opt for arbitration: «L'arbitrage est le mode les plus fréquent de résolution des litiges du commerce international. La raison principale du succès qu'il remporte auprès des justiciables est sa neutralié, liée à son caractère privé : les arbitres ne statuant pas au nom d'un Etat, mais uniquement en leur nom propre, ne sont pas soupçonnés de partialité envers l'une ou l'autre partie », P. Mayer, L'autonomie de l'arbitre international dans l'appréciation de sa propre compétence, COLLECTED COURSES, 1989-V, vol. 217, (319), 327.

59 Most notably the New York Convention on the Recognition and Enforcement of Foreign Arbitral Awards, 10 June 1958, 21 U.S.T. 2517, 330 U.N.T.S. 38, in force in more than 100 countries.

The success of the New York Convention is even more remarkable if one thinks of the absence of a worldwide Judgments Convention. This means that, for a variety of reasons, States have agreed to give more respect to private justice than to each other's justice.

There is also a fierce competition between « different arbitral institutions hawking their wares ", as D.F. Vagts, Dispute-Resolution Mechanisms in International Business, CoLLECTED COURSES OF THE HAGUE ACADEMY FOR INTERNATIONAL LAW 1987-III, vol. 203, (9), at p. 8.

61 See for instance two ground-breaking rulings of the U.S. Supreme Court, Scherk v. AlbertoCulver Co. 417 U.S. 506 (1974) (the Court held that the fact that the U.S. securities legislation applied to the transaction at hand did not mke the dispute non-arbitrable); Mitsibishi Motors Corp. Soler Chrysler-Plymouth, Inc., 105 S. Ct. 3346 (1985) (the Court held that an arbitration clause between an Japanese manufacturer and an American distributor was valid even though the distributor complained of violation of U.S. antitrust legislation). On this last case see J. Robert, "Une date dans l'extension de l'arbitrage international : l'arrêt Mitsubishi c. Soler ", [1986] Rev. Arbitrage 173 and the controversy between T. Carbonneau, "Mitsubishi : The Folly of Quixotic Internationalism », 2 Arb. Int'l 116 (1986) and A. Lowenfeld, « The Mitsubishi case : Another View », 2 Arb. Int'l 178 (1986). 
conciliation, etc, the basic idea remains the same : instead of agreeing to submit to the binding resolution of a dispute according to rules of law, parties choose to work out their differences through negotiation, with or without the help of a third party or of a simulated trial. Characteristic of this approach is that parties are not bound by legal rules and do not await a solution imposed on them. The consequences of this evolution for the concept of jurisdiction have yet to be worked out.

The recognition of consent as a general principle of jurisdiction goes hand in hand with the greater weight given to parties in the selection of the applicable law. Party autonomy also dominates conflict of laws rules, both in Europe ${ }^{62}$ and in the United States. ${ }^{63}$

18. However, choice of court agreements (and choice of law agreements) cannot resolve all issues. For one thing, party autonomy is only recognised in certain fields. Parties involved in divorce proceedings are rarely afforded the freedom to determine which court will hear their claim. ${ }^{64}$ On the other hand, the principle of party autonomy "has been given effect in a number of different ways" ${ }^{65}$ The result is that "It is by no means the case [...] that [...] jurisdiction (or arbitration) agreements foreclose the possibility of often decisive interlocutory litigation on the question of venue for and or mode of the resolution of disputes arising between parties to such contracts. The law reports record many instances of litigation by parties 'in order to determine where they shall litigate' notwithstanding the existence of a jurisdiction clause or arbitration agreement". 66

Litigants can too often wriggle out of jurisdiction agreements, on the basis of convenience arguments or other. It remains that the principle of party autonomy has acquired today a fundamental value and constitutes indisputably an acquis of the modern law of jurisdiction.

\section{Prohibition of 'jurisdictionally improper fora'}

19. Beyond the demise of pure territoriality and the rise of consent, the last general principle that can be singled out is the prohibition of certain grounds of jurisdiction, deemed too self-serving. It has become commonplace to refer in this respect to 'exorbitant' or 'improper' ${ }^{67}$ fora.

It is often said that the exercise of jurisdiction should be founded on a 'minimum connection' or a 'genuine link' between the State claiming jurisdiction and the dispute. ${ }^{68}$

62

See Article 3 of the 1980 Rome Convention: "A contract shall be governed by the law chosen by the parties. The choice must be expressed or demonstrated with reasonable certainty by the terms of the contract or the circumstances of the case. By their choice the parties can select the law applicable to the whole or a part only of the contract".

See e.g. $\S 187$ Restatement of the Law, Conflict of Laws $2^{\text {nd }}$ : "The law of the state chosen by the parties to govern their contractual rights and duties will be applied if the particular issue is one which the parties could have resolved by an explicit provision in their agreement directed to that issue"

Except maybe when the divorce petition is brought by the two spouses together, see Article 2(1)(a), fourth hypothesis of EU Regulation 1347/2000.

C. MCLACHLAN, "Third Interim Report : Declining and Referring Jurisdiction in International Litigation", International Law Association. Report of the London Conference 2000, 5.

A. S. BELL, "Jurisdiction and Arbitration Agreements in Transnational Contracts", J. Contract L., 1996, (53), 54. See also Chapter 5 of Mr. Bell's recent book, referred to supra Note 1, entitled 'Escaping the Bargain' (at pp. 283 to 333).

After the title of Mr. Nadelmann's essay, “Jurisdictionnally Improper Fora”, in Legal Essays in Honor of H. E. Yntema, Leyden, 1961, $321 \mathrm{ff}$.

F. A. MANN, referred to the concepts of 'genuine link', 'sufficiently strong interest' and 'reasonable relation' (The Doctrine of Jurisdiction in International Law, COLLECTED COURSES, 1964-I, t. 111, (9-162), 46-47. See also G. BORN, Reflections on Judicial Jurisdiction in 
The only practical translation of this very general principle is in effect that the idea that some rules of jurisdiction are objectionable, in that they do not guarantee that the court will show the desired minimum link with the dispute.

This idea has been taken over in various international agreements. Both the Brussels Convention ${ }^{69}$ and the 1971 Hague Enforcement Convention ${ }^{70}$ contained a catalogue of grounds of jurisdiction whose exercise is prohibited between Contracting Parties. ${ }^{71}$

The Draft Hague Convention of 2001 goes one step further. Besides the general catalogue of prohibited grounds of jurisdiction, Article 18(1) of the 2001 Draft Hague Judgments Convention also contains a general prohibition of the exercise of any jurisdiction that is not founded on a "substantial connection" between the State exercising jurisdiction and the dispute. ${ }^{72}$ The second part of this provision goes on to single out a series of rules of jurisdiction that are presumed not to satisfy this general test. ${ }^{73}$

20. The educational value of the black lists of exorbitant fora cannot be underestimated. It must be said however that the 'minimum connection' principle they convey, is probably much less firmly well established than the first two general principles singled out in this essay.

On the one hand, the prohibition of certain fora only works well when it is the object of a mutual pact. It goes without saying that States are much less willing to compromise on their traditional grounds of jurisdiction in the absence of the reciprocity of a bargain, even if it is impossible to ignore the unreasonable nature of certain claims for jurisdiction.

International Cases, GeORGIA J. INTL. L., 1987, (1), 19 (who sees an "emerging principle of international law requiring assertion of judicial jurisdiction to be reasonable") and G. VAN HECKE, Principes et méthodes de solution des conflits de lois, COLLECTED COURSES, 1969-I, t. 126, (399), 418. See more recently, J. Bertele, SOUVERÄNITÄT UND VERFAHRENSRECHT. EINE UNTERSUCHUNG DER AUS DEM VÖLKERRECHT ABLEITBAREN GRENZEN STAATLICHER EXTRATERRITORIALER JURISDIKTION IM VERFAHRENSRECHT, Tübingen, Mohr Siebeck, 1998, at pp. 182-185 ("Genuine Link") and the references quoted by P. de Vareilles-Sommières, o.c., 1997, at p. $243, \S 394$.

Originally, the catalogue of prohibited grounds appeared directly in the text of the Convention, even though it did not add anything to the first part of Article 3 of the Convention, which already stated that parties domiciled in a Member State could only be sued on the basis of the grounds of jurisdiction expressly recognised by the Convention. Recently the famous black list was removed to an Annex of the EU 44/2001 Regulation.

70 Article 4 of the Additional Protocol to the 1971 Hague Enforcement Convention.

71 The European 'black' list is drafted with reference to specific provisions of national law, whereas the Hague 'black' list is drafted in abstract terms, with reference to jurisdiction claims that should be prohibited whatever their precise legislative or jurisprudential translations.

Article 18, entitled Prohibited grounds of jurisdiction, reads as follows : "(1) Where the defendant is habitually resident in a Contracting State, the application of a rule of jurisdiction provided for under the national law of a Contracting State is prohibited if there is no substantial connection between that State and the dispute".

"(2) In particular, jurisdiction shall not be exercised by the courts of a Contracting State on the basis solely of one or more of the following :

- the presence or the seizure in that State of property belonging to the defendant, except where the dispute is directly related to that property;

- the nationality of the plaintiff;

- the nationality of the defendant;

- the domicile, habitual or temporary residence, or presence of the plaintiff in that State;

- the carrying on of commercial or other activities by the defendant in that State, except where the dispute is directly related to those activities;

- the service of a writ upon the defendant in that State;

- the unilateral designation of the forum by the plaintiff;

- proceedings in that State for declaration of enforceability or registration or for the enforcement of a judgment, except where the dispute is directly related to such proceedings;

- the temporary residence or presence of the defendant in that State;

- the signing in that State of the contract from which the dispute arises". 
Unilateral disarmament is as difficult in the field of jurisdiction as in other fields of human activities...

On the other hand, even rules that are objectionable in principle can be acceptable in certain contexts. This is the case with the infamous forum actoris, i.e. a rule that links the exercise of jurisdiction to certain characteristics of the plaintiff, such as his domicile or nationality. This is in principle objectionable, as the European Court of Justice regularly repeats in the framework of the Brussels Regulation. However, the forum actoris may be justified in the field of family law, e.g. when it comes to jurisdiction in matters of divorce. How else can the Italian wife of an Belgian man obtain a divorce in her home country when the husband has left the matrimonial home in France and returned to Belgium ? ${ }^{74}$

Finally, one should not forget that Article 18 of the Draft Hague Convention was the subject of strong criticism, mainly by U.S. experts who found it too restrictive. There is reason to think that it would not have been accepted as it stood in the 2001 Draft.

21. All this considered, we might need to reduce the third principle to a simple prohibition of discrimination against foreigners in assertion of jurisdiction. It is uncertain whether there is enough agreement to go beyond this general prohibition.

The recent evolution of some national laws gives, however, reason to be optimistic. One of the clearest signs of change is the recent revision of the Dutch Code of Civil Procedure. This process has led to the disappearance of the infamous Article 126 of the Wetboek van Burgerlijke Rechtsvordering, which embodied one of the crudest forms of forum actoris. ${ }^{75}$ Similarly, Spanish and Italian rules on jurisdiction were reformed in the last decade to incorporate many of the rules of jurisdiction found in the Brussels Convention, thereby doing away with older rules that were not always free from bias against foreigners and foreign courts. At the same time, the general acceptance of the doctrine of forum non conveniens in common law systems has contributed to the refinement of excessively broad traditional rules of jurisdiction. ${ }^{76}$ If only France could follow the example of its European neighbors and do away with the Articles 14 and 15 of its Civil Code!

\section{An attempt to conclude : the differences that separate us}

22. Once upon a time, it was thought that States could easily agree on generally acceptable rules of jurisdiction. The famous Dutch internationalist, Tobias Asser, wrote at the end of the $19^{\text {th }}$ century that "il ne sera pas difficile, croyons-nous, de déterminer, pour chaque procès, quel en est le juge naturel et d'arriver sur ce point à un accord international".

74 See Article 2 of the Brussels II Regulation 1347/2000, which grants jurisdiction to the courts of the habitual residence of the plaintiff, provided the plaintiff resides in the Member State for at least 12 months - or 6 months in case the plaintiff is a national of the country.

75 See for a comment, P. Vlas and F. Ibili, "De nieuwe commune regels inzake de rechtsmacht van de Nederlandse rechter", W.P.N.R., nr. 652, at pp. $310 \mathrm{ff}$. LGDJ, 2003, 973 p., in particular at pp. 161-201.

77 T. M. C. Asser, ElÉments DE DROIT InTERnAtIONAl PRIVÉ, Paris, Rousseau, 1884, 154 - it is interesting to note that the only principle Asser put forward to found jurisdiction was what would later be called 'Gleichlauf', i.e. the idea that the court of country A should have jurisdiction when the law of country A applies. 
One cannot but accept that these dreams have not (yet?) been fulfilled. ${ }^{78}$ There is no agreement today on a detailed framework for international adjudicative jurisdiction in private matters.

This essay attempted to draw the lines around three general principles, on the (naïve?) presumption that most jurisdictions would have no difficulty to approve them.

Beyond these basic tenets, disagreements abound. It is difficult to single out other principles of private international jurisdiction that could count on the same general approval. Even the 'forum sequitur actor rei'-principle - granting general jurisdiction to the courts of the domicile of the defendant - is not wholly uncontested. It has been argued that « Legal systems agree that natural persons may be sued at their domicile on any claim " ${ }^{79}$ One can however doubt whether this rule would in all instances pass the 'due process' test laid down by the US Supreme Court in International Shoe. There is certainly disagreement on the importance of the rule : some see it as the most fundamental principle, to which all other rules should be subordinated; other refuse to grant it any special status. On a more theoretical plane, the idea that the defendant deserves special protection is certainly not unchallenged.

23. Once the solid core of generally accepted principles is identified, one should attempt to single out areas of disagreement. The task is infinite. By way of conclusion, we will outline two of the main problem issues that stand in the way of general agreement on private international jurisdiction.

The first one is an issue of legal technique. ${ }^{80}$ Careful students of the numerous documents produced by the Hague attempt to draft a worldwide Jurisdiction Convention will soon notice that the process often stumbled on issues of drafting. There is probably a general agreement that a distinction should be between rules granting general jurisdiction (for all disputes) and rules granting special jurisdiction (for a specific category of disputes).

Beyond this very general distinction, one can distinguish two models that compete for attention. ${ }^{81}$ On the one hand there is the 'Brussels' model, made up of 'hard and fast' rules leaving little room for flexibility, which typically focus on a well-defined category of disputes. This approach, called 'Typisierung' in the German doctrine, is exemplified by Article 5-1 of the Brussels Regulation, the basic European rule for disputes in contractual matters.

Article 5-1 selects a single one element of the contractual relationship, i.e. the place of performance of the obligation in dispute, ${ }^{82}$ which is deemed to determine jurisdiction in all

This is not for lack of effort by scholars. Some internationalists took up Asser's challenge and drafted a model conventions providing uniform rules on international jurisdiction for the courts of all Nations. See the attempts made by H. SPERL, Eine internationale Zuständigkeitsordnung in bürgerlichen Rechtssachen, published in ZEITSCHRIFT FÜR INTERNATIONALES RECHT (NIEMZ.), 1925, $19 \mathrm{ff}$ and the draft convention elaborated by the Dutch lawyer J. Kosters, BIJDRAGE TOT INTERNATIONALE REGELING DER RECHTSMACHT IN BURGERLIJKE EN HANDELSZAKEN, Haarlem, De Erven F. Bohn, 1914, 107 p.

79 P. HAY, Flexibility versus Predictability and Uniformity in Choice of Law - Reflections on Current European and United States Conflict of Law, COLLECTED COURSES, 1991-I, vol. 226, (281), at p. 311.

80 An issue underlined by J. Hill, Jurisdiction in Civil and Commercial Matters : Is There a Third Way? ? CURRENT LEgAL PROBlems, OUP, 2001, 439-476.

81 See generally on this distinction, T. PFEIFFER, Internationale Zuständigkeit und Prozessuale Gerechtigkeit. Die internationale Zuständigkeit im Zivilprozess zwischen effektivem Rechtsschutz und nationaler Zuständigkeitspolitik, Frankfurt a.M., Vittorio Klostermann, 1995, at pp. $199 \mathrm{ff}$.

82 And for some categories of contracts, the characteristic obligation. See on the new Article 5-1, P. VLAS, "Stoeien met verbintenissen, worstelen met art. 5 sub 1 EEX-Verordening", W.P.N.R., 2002, nr. 6485, at pp. 301-302. 
contractual disputes, whatever their nature and shape. This certainly provide for a good deal of certainty - even though the drafting of the provision is itself source of uncertainty and dispute. The certainty comes, however, at the cost of some unwanted results, no the least in determining whether the dispute is concerned with a contract. Other problems abound, most disturbing of all the fact that Article 5-1 fails to give appropriate weight to other connecting factors which may be as relevant as the place of performance of the characteristic obligation. Finally, one is at loss to locate the place of performance of an obligation to refrain to do something. It is therefore no surprise that Article 5-1 has given rise, not only to a real cottage industry in the legal literature, spawning commentaries in all languages but invariably critical, ${ }^{83}$ but, more troublesome, to a long list of references to the Court of Justice by national courts seeking help in interpreting the European forum contractus.

The second model, which can somewhat arbitrarily be called the 'English' model, avoids the pitfalls of Article 5-1 in that it builds on an ad hoc decision making on the basis of flexible criteria. This case-by-case approach - 'individuele Einzelfallabwägung' in the German terminology - gives rise to open-ended, open-textured jurisdiction rules, which are qualified by a very broad discretion of the court. This is where the forum non conveniens doctrine comes into play, giving the court the power to refuse to exercise jurisdiction when it deems it inappropriate.

This sounds attractive in principle, but is certainly not free from side effects. The most troublesome of which is that the 'English' model leads to speculative litigation on jurisdictional question and wasteful litigation to determine the place of litigation.

The choice between these regimes, presented here without much nuance, is influenced by the eternal debate between legal certainty on the one hand and the need for flexibility on the other, which is in turn heavily dependent on one's legal upbringing. A common lawyer may think that " the life of law has not been logic; it has been experience " ${ }^{84} \mathrm{~A}$ lawyer educated on the old continent will shiver when reading MM North and Fawcett's statement that « Private international law is no more an exact science than is any other part of the law of England ; it is not scientifically founded on the reasoning of jurists, but it is beaten out on the anvil of experience $" .{ }^{85}$

This is not to say that the two models cannot be reconciled. There are ways to bridge the gap and the process of negotiating the Hague Judgments Convention showed the way. Unfortunately, this process has failed, at least in its early, ambitious form.

24. Beyond mere drafting problems, the search for common ground is also mired by issues of principles. The very first of these is the need to define which objectives should command when defining the limits of jurisdiction. German doctrine speaks in this respect of 'Zuständigkeitsinteressen'.

An agreement can certainly be found that jurisdiction is not a valueless, abstract process, but also embodies substantive policies. Unlike choice of law rules, rules of jurisdiction have never been thought of as mere conceptual rules, whose sole function would be to allocate power between competing nation-states. The student of jurisdiction will very

83 See e.g. G. A. L. Droz, "Delendum est forum contractus ?", D., 1997, Chron., 351-356; V. HeuzÉ, "De quelques infirmités congénitales du droit uniforme : l'exemple de l'article 5-1 de la Convention de Bruxelles du 27 septembre 1968", Revue critique de droit international privé, 2000, $595 \mathrm{ff} ; \mathrm{H}$. MUIR WATT, "Peut-on sauver le for européen du contrat?", Rev. Générale des procédures, 1998, $371 \mathrm{ff}$. and L. PALSSON, "The Unruly Horse of the Brussels and Lugano Conventions : the Forum Solutionis", in Festkrift für Ole Lando, L. L. ANDERSEN (éd.), Copenhagen, 1997, 259 e.s Butterworths, 1999, at pp. 31-32. 
soon discover that there is more to jurisdiction than neatly 'compartmentalizing' disputes according to their territorial or personal connections. ${ }^{86}$

It should not be too difficult to agree that jurisdiction can be influenced by a variety of principles, such as concerns for sovereignty - giving rise to rules founded on the nationality of parties or on the location of real property - and concerns for the need to regulate human activity on a given territory - leading to rules pegging jurisdiction to the effects of certain conducts in a State. Principles of 'fairness' and 'justice' can probably also receive approval, and lead to rules based on the need to protect the defendant or ensure that a dispute is allocated to a court convenient for all parties involved.

Besides these jurisdictional principles, one can probably agree that other objectives also deserve attention, such as the need to avoid parallel litigation, concerns for forum shopping or the idea that jurisdiction should go hand in hand with a well thought of recognition policy. The 'meta-jurisdictional' principles also include the need to further substantive policy objectives, such as concerns for protecting 'weaker' parties.

Identifying general principles is one thing. Determining which principle deserves priority in a given case or reconciling principles which lead to contradicting outcomes, can prove much more difficult. The first question one should address is whether there is a need for some sort of hierarchy between competing principles. This is a delicate task, for all principles seem worthy of attention. ${ }^{87}$ The US Supreme Court seemed to recognise that it is illusory to pretend that a single most important concern can be singled out, when it held that « the burden on the defendant, while always a primary concern, will in an appropriate case be considered in light of the relevant factors, including the forum State's interests in adjudicating the dispute ; the plaintiff's interest in obtaining convenient and effective relief [...] at least when that interest is not adequately protected by the plaintiff's power to choose the forum [...]; the interstate judicial system's interest in obtaining the most efficient resolution of controversies and the shared interest of the several States in furthering fundamental substantive social policies" ${ }^{88}$

25. In the end, theories on jurisdiction may be in a 'transitional' period. General principles have been identified, as have been areas of disagreement. We may safely conclude that jurisdiction is a complex equation, ${ }^{89}$ one that requires that the relationship between the various principles be elucidated.

Whatever weight is given to each element of this equation, the drafter of the rule will need to remember that globalization brings about more and more 'pluri-localised' situations, i.e. situations that have substantial connections with more than one State. If one remembers that assertions of jurisdiction must answer to many competing interests, it is easy to accept that the idea of a single natural forum for each dispute is an illusion. ${ }^{90}$

$86 \quad$ On this theme see already PH. FRANCESCAKIS, review of the $4^{\text {th }}$ edition of Batiffol's Droit international privé, in Revue critique de droit international privé, 1967, (435), at p. 437. See also T. PFEIFFER, "Materialisierung und Internationalisierung der internationale Zuständigkeit", in 50 Jahre BGH. Festgabe aus der Wissenschaft, C.-W. CANARIS (ed.), München, Beck, 2000, III, at pp. 617-653.

This is the major flaw of Schröder's study (Internationale Zuständigkeit. Entwurf eines System von Zuständigkeitsinteressen im zwischenstaatlichen Privatverfahrensrecht aufgrund rechtshistorischer, rechtsvergleichender und rechtspolitischer Betrachtungen, Opladen, Westdeutscher Verlag, 1971, 852 p.) : although it clearly identifies all relevant principles, it does not offer a key to understand their relationship.

$88 \quad$ Worldwide Volkswagen Corp. v. Woodson, 444 U.S. 286, 292 (1980).

89 A phrase used A. T. von Mehren, Conflict of LAWS : AmERICAN, ComparatiVe, InTERnATIONAL, CASES AND MATERIALS, St. Paul, West, 1998, at p. 736. hommage a J. Gaudemet, C. Bontems (ed.), Paris, PUF, 1999, at pp. 591-612. 
We should therefore start from the premise that several States will be able to claim jurisdiction for the same dispute and move towards the idea of cooperation between States with a substantial interest in solving the dispute. Jurisdiction should not be thought of as a unilateral decision by a single State, but more as an exercise in cooperation between the States involved. 